Compound No. 1 is the normal 'nitrogen mustard'. When for the methyl group is substituted an isopropyl group (No. 2) both the mutagenic activity and the toxic effect decrease. The two next compounds are both 'monochloro mustards'. No. 3 has already been found to be mutagenic by Stevens ${ }^{2}$. The mutagenic effect of Nos. 3 and 4, together with the data of Stevens ${ }^{2}$ and of Auerbach and Moser ${ }^{3}$, shows that the effect of the 'mustard gas' molecule does not depend on its ability to form cross-linkages with the protein, as assumed by several authors ${ }^{4,5}$, since this reaction assumes the existence of two active chlorine atoms. This is further supported by the negative results obtained from compounds 5 and 6 , both of which should be able to form cross-linkages.

None of these compounds is, however, able to form iminium ions similar to the ion,

$$
\mathrm{CH}_{3} \stackrel{+}{-}-\mathrm{CH}_{2} \mathrm{CH}_{2}
$$

which, as already pointed out by Gilman and Philips seems to be the first step in the reaction of the 'nitrogen mustard' molecule. Hence we conclude that it is the ability of the molecule to form the highly reactive iminium ion which is the prerequisite for the biological activity of the 'mustard gas', and that the level of activity determines the level of mutagenicity as well as toxicity, since the larger and therefore less reactive molecules of compounds 2 and 4 are less active than compounds $I$ and 3 respectively. As a working hypothesis it still seems most likely that the mutations are induced by the release of energy from the reactions of these very reactive compounds.

Chemical Laboratory,

K. A. JENSEN

\section{University of Copenhagen.}

Genetical Institute,

University of Copenhagen. Sept. 19.

1 Kolmark, G., and Westergard, M., Hereditas, 35, 490 (1949).

2 Stevens, C. M., and Mylroie, A. (see previous letter).

${ }^{3}$ Auerbach, C., and Moser, H. (see preceding letter).

-Goldscre, R. J., Loveless, A., and Ross, W. J. C., Nature, 168, 667 (1949).

- Loveless, A., and Revell, S., Nature, 164, 938 (1949).

- Gilman, A., and Philips, F. S., Science, 103, 409 (1946).

\section{FRESHWATER BIOLOGICAL ASSOCIATION}

\section{OPENING OF WINDERMERE LABORATORY}

$\mathrm{O}$

September 23 the Countess of Albemarle, chairman of the Development Commission, formally opened the new laboratory of the Freshwater Biological Association at the Ferry House, Far Sawrey, Ambleside, Westmorland, on the western shore of Windermere. The Ferry House stands on a small promontory projecting from the western shore of Windermere mid-way between the ends of the Lake. The site, of some $2 \frac{1}{2}$ acres, is almost surrounded by water. A road past the building to the tip of the pro. montory leads to a cable-ferry to the Bowness shore 560 yards away. The main building was built of local stone in $1880 \mathrm{as}$ a hotel of some forty bedrooms. Its rooms are of convenient sizes and well provided with windows. On the ground floor are the library, a common room, a large laboratory for the use of classes and visiting scientific workers, a dining-room and domestic offices, a small electrical workshop, and laboratories used by assistants and for the supply of biological material to universities and schools. The first floor contains administrative offices and fourteen rooms fitted as laboratories, mostly of a size suitable for one person but providing bench space for seven. teen or eighteen scientific workers altogether. One of these is fitted as a chemical laboratory, and there are also two dark-rooms and a small store-room. The top floor provides living quarters for some members of the staff and also for visitors who come to work in the laboratory. A semi-basement, which opens at ground-level on one side of the building, contains a room into which samples, fish, and collections of all kinds can be brought from boat or car for sorting, cleaning or washing. There also are workshops, stores, a room for algal cultures and one for aquaria. On the other side of the road is a garage and stable block, which provides further storage space and several small rooms on an upper floor. There is at present no boathouse, but it is hoped to build one on the shore of a sheltered bay adjacent to the garages. Besides smaller boats in which outboard motors can be used, the Association has a 36-ft. motor launch with a roomy cabin, from which most of the work on Windermere is done. Row-boats are also kept on certain other lakes, and a smaller craft which can be towed in a trailer behind the large shooting-brak $\theta$ makes it possible to obtain samples from lakes on which there are no boats.

The opening ceremony was attended by some three hundred people, including representatives of the Rnyal Society, the Ministry of Agriculture and Fisheries, and several of the universities. The president of the Freshwater Biological Association, Mr. Reginald Beddington, in an introductory address, recalled that the foundation of the Association twenty-one years before, in June 1929, resulted from a jnint dis. cussion held by Sections D (Zoology) and $\mathbf{K}$ (Botany) of the British Association for the Advancement of Science at the Glasgow meoting of 1928. He also referred to the fact that it was on September 23, 1931, that the Association's scientific staff began work at Wray Castle.

Prof. F. E. Fritsch, chairman of the Council of the Association, gave an account of the objects for which the Association was founded and of the work carried on. After referring to the award to the Association of the Einar Naumann Medal at the International Limnological Congress in Zurich in 1948, Prof. Fritsch said : "It is comparatively simple to state our aims in establishing the laboratory, namely, to study the conditions of life of the organisms inhabiting fresh waters and especially those not seriously affected by human interference. We wish to ascertain the composition and distribution of the fauna and flora inhabiting such waters and the factors beneficial to the life within them, so as to provide a better basis for the assessment of the effects of pollution and the study of other problems encountered in the utilization of water and the maintenance of populations of fish. These projects are far-reaching and, as usual in research of any kind, every fresh discovery has opened up new avenues for investigation and widened the horizon to be embraced."

Prof. Fritsch referred to the work of Dr. T. T. Macan in relating the larvæ of insects to their adult stages, of Dr. J. W. G. Lund on the planktonic plants, and of Dr. H. M. Canter on the Chytrid fungi parasitie 
on the plankton algæ. He said that one of the main concerns of the Association has been to investigate the conditions determining the productivity of a water, a laborious proceeding since it entails frequent counting of the numbers of certain species together with regular chemical analyses of the water and records of light, temperature and other environmental factors. In this field Dr. C. H. Mortimer and Mr. F. J. H. Mackereth have added to the knowledge of the physical and chemical properties of lakes and have introduced improved methods of investigation. The study of the seasonal changes in the animal and plant life of a lake has revealed their cyclical nature and the importance of the surface layers of the bottom mud as the main site of the processes of decay which result from bacterial action. The Council has recently taken steps to provide for more intensive work on the role of bacteria in fresh-waters. In the investigation of the bottom sediments, the Association is much indebted to Mr. B. M. Jenkin for the design and construction of special apparatus for lifting entire cores to the surface. The study of such cores by Mrs. T. G. Tutin has shown that they are by no means only of geological interest, but may provide a historical background to the studies on productivity. The Council therefore hopes to resume these investigations which have been temporarily allowed to lapse.

Prof. Fritsch referred next to the work of Mr. K. R. Allon, Dr. W. E. Frost and Mr. E. D. Le Cren, all of whom have contributed to the knowledge of the biology of various species of fish. A large-scale ecological experiment begun by Dr. E. B. Worthington, in the course of which about 95 tons of perch and many large pike have been removed from Windermere since 1941, is still in progress, and the effects of this disturbance of the balance of the fish population will only gradually become apparent. Among the significant changes already observed is an increase in the breeding stock of char, which were seen spawning in the River Brathay in 1948 for the first time for forty years.

Hitherto the Association's work on fish has been observational rather than experimental, and concerned more with static than with flowing waters. The acquisition of a lease of Wraymires hatchery and fish-ponds, $2 \frac{1}{2}$ miles from the Forry House, provides opportunities for ecological, physiological and genetical experiments on the problems connected with the growth of fish. Moreover, the Council now feels that sufficient progress has been made with fundamental researches to approach with confidence the more difficult problems of rivers. It is therefore hoped to establish a second smaller laboratory on one of the southern rivers, in order to extend the scope of the research, especially on certain fish, and to make possible the comparison between conditions in the streams of the Lake District and those in a southern chalk stream.

Mr. Beddington then spoke of the help and support the Association has received from the Development Commissioners and from their secretary, Mr. E. H. E. Havelock, and called upon the Countess of Albemarle to declare the new laboratory open. Lady Albemarle paid tribute, for their work on the Association's behalf, to Mr. Beddington, Prof. Fritsch, Prof. W. H. Pearsall, Mr. J. T. Saunders, the second Lord Rothschild, who was the first president, and the late Sir Albert Atkey, who was honorary treasurer for many years. The Association also owes much to its staff, especially Mr. P. Ullyott and Mr. R. S. A. Beauchamp who began the work under Prof. Pearsall's guidance,
Dr. E. B. Worthington, the first director, and not least the present director, Mr. H. C. Gilson, on whom has fallen the task of seeing that the Ferry House should be ready that day.

The Development Act of 1909, continued Lady Albemarle, made no reference to freshwater biology, nor indeed to research in connexion with fisheries, though research was specifically mentioned in relation to agriculture. From the first the Commissioners worked to ensure that the resources of science should be brought to bear on the practical problems of fisheries, bearing in mind that they were instructed to promote economic development. Since the Com. missioners were also concerned with the general welfare of the countryside, they did not limit themselves to the interests of commercial net fisheries. Nevertheless, they had to consider aid for freshwater fishery research from the economic point of view; and the amount of money which could be made available was therefore limited and had to be related to other claims on the Development Fund.

To advise on the principles which should guide the spending of this money, the Commissioners in 1919 appointed an Advisory Committee on Fishery Research. The chairman was Sir William Hardy, the other scientific members being William Bateson, W. M. Bayliss, G. C. Bourne, H. H. Dale, Walter Garstang, John Graham Kerr, E. W. MacBride and R. E. Scharff; two laymen interested in the imme. diate problems of deep-sea and inshore fishermen, G. C. L. Howell and Harold Wright, were also members. This committee's report contained the following passages, which although they related to sea fisheries were also relevant to those in fresh water : "... nothing less than a complete knowledge of the sea and the life in it, and especially the interdependence between fish problems and all the conditions of fish life, will suffice to form a rational basis for fishery development. . . . Another principle governing the organisation of research is that opportunity must be given for the appearance and growth of new ideas. It is impossible at the outset to say what ideas will lead to results of economic importance. . . The real problem, as the Committee conceive it, is not to distinguish whether this or that class of research, free or economic, pure or applied, is most likely to lead to immediate practical results, but to detect and secure that organisation which shall best promote the development of the fisheries by the increase of the knowledge of all marine life."

For administrative purposes the Advisory Com. mittee adopts a distinction between 'directed' research financed through government departments and 'free' research which is supported in independent laboratories. There is general scientific supervision of programmes and of the quality of the work by the Advisory Committee, but the Commissioners have never attempted the impossible task of determining whether or not a particular part of a programme is likely to have economic value. It is essential that the closest relations should be developed between, on one hand, the growing staffs of the Fisheries Departments and of the Water Pollution Research Board of the Department of Scientific and Industrial Research and, on the other, those whose future base would be the Ferry House. The first necessity is to identify the major practical problems, so that those whose task is to build up basic knowledge of all the aspects of life in river, stream and lake can bear those problems in mind; then their fundamental research will be, in 
the words of Sir Edward Appleton, "objective fundamental research". The choice of subjects for "free' research is difficult and, when freedom is given, the temptation to pursue fascinating by-paths merely for the sake of exploration must be resisted. The Com. missioners hope that, by choosing staffs wisely and giving them the accommodation they need, it will be possible to build sound foundations.

In considering priorities after the Second World. War in the light of the principles laid down by the original Advisory Committee, the Commissioners have been advised by a special committee of which Sir John Graham Kerr is chairman. This committee discusses with representatives of the Association a memorandum on post-war development prepared by the Council. Its recommendations for the strengthening of both staff and equipment, especially in the fields of algology and bacteriology, have now been implemented to a considerable extent. For accommodation the Association has been exceptionally fortunate in finding the Ferry House, for it would otherwise have been necessary to remain for some five years at Wray Castle and then acquire land on which to build afresh.

\section{MANCHESTER COLLEGE OF TECHNOLOGY}

\section{EXTENSION OF THE DEPARTMENT OF MECHANICAL ENGINEERING}

$\mathrm{A}^{\mathrm{n}}$

FTER numerous recent discussions of plans for technical education at the higher levels, it may be refreshing to consider the way in which older provision has been developed in an endeavour to meet modern requirements. One such opportunity has been provided by the formal opening by Mr. Louis Mather on December 7 of the first part of the extension to the Manchester Municipal College of Technology, namely, that devoted to mechanical engineering.

The College, which was founded as a Mechanics Institute in 1824, has a double role, first as the major technical college in a wide regional scheme and dealing with subjects at an advanced level (higher national certificates, special and refresher courses, etc.), and secondly as incorporating the Faculty of Technology of the University of Manchester, with which it was integrated in 1903, and working for the Bachelor's, Master's and Doctor's degrees. The happy blending of these two functions, with marked advantages to both sides, is a major feature of the work of the College, and provides opportunities for developments, particularly in connexion with part-time activities.

Though the building completed in 1903 stands as a majestic monument to the courage and wisdom of its founders, provision was made for its growth, and the extension under construction, which will double the original size, forms an integral part of the whole: The section now being opened contains one very large single-storey laboratory, several smaller laboratories and stores, offices for members of the staff, and two drawing offices. Alternative accommodation is also provided for other departments, and will enable the Department of Mechanical Engineering to exterd considerably its laboratory facilities in the older building. Though schemes developed since the commencement of construction, delayed by the War, have necessitated changes in the purposes to be served by the various rooms, these have been skilfully adapted, and the general impression is one of fitness and great dignity. The full provision of offices for the staff and of a departmental committee room will not be available for a few months, but the facilities for quiet study and undisturbed consultation, so often overlooked, have received appropriate attention. It will be a little time yet before the full adjustments in the older building are completed, but there is no doubt that the final result will be very good.

Though the arrangements made in 1903 were considered very lavish, it is interesting to note that five laboratories and access to the College power-house were considered adequate to cover the various branches of mechanical engineering exclusive of craft-work, which is now dealt with elsewhere. In contrast, the later developments in engineering science and technology, and the refinements of modern methods, now call for more than four times this provision. For example, the measurement of the fundamental engineering quantities, such as size and form, temperature and heat, quantity, pressure and velocity of flow, which formerly occupied only small sections of general laboratories, now require separate provision and call for a degree of specialized knowledge and skill which, combined with work of a more traditional nature, make the selection and training of staff a far more formidable task than in earlier days. Nor can the requirements of modern industry in respect to such measurements be considered as essentially of a lower order than those for research. There are no separate research laboratories. It is a deliberate policy throughout the Department to bring teaching and research into close relationship so that the student becomes conscious of the refinements which can be made to the relatively simple apparatus which he himself uses, of the skill required in their handling, and of the concentration and care needed in planning, carrying out and completing an experimental investigation. Through the help given in the laboratories to industrialists seeking the advice and assistance of members of the staff, the student becomes aware also of the close relationship of his own task to the needs of the profession he is seeking to follow-a matter which too easily becomes obscured, to his considerable discouragement:

The equipment of the Department can be classed roughly under headings : (1) normal teaching equipment, (2) equipment for precise basic measurement, (3) special-purpose plant for specific investigations; but such a classification is far from satisfactory. For example, the precision measuring equipment may well be required to illustrate the logical development of the apparatus actually handled by the students, as well as being fundamental to research, while the systematic planning of research ensures that, through the medium of the equipment required, it will contribute to the work of the Department as a whole. It is interesting that research projects, though very frequently arising from discussions with the representatives of industry and receiving much help from them, are entirely under the control of the head of the Department, and that, in fact, suggestions for work which might be considered as routine or developmental are scarcely ever made.

The contribution of industry to the equipping of the Department, whether for teaching or research, is remarkable, both for its liberality and for the co-operative spirit in which it is made. It may take the form of raw material, a complete major unit of 